\title{
Growth, Photosynthetic Efficiency, Rate of Transpiration, Lodging, and Grain Yield of Tef (Eragrostis Tef (Zucc.) Trotter) as Influenced by Stage and Rate of Paclobutrazol Application
}

\section{T. Tekalign}

Haramaya University, Department of Plant Sciences, P O Box 150, Ethiopia

Email: tekaligntsegaw@yahoo.com

\begin{abstract}
The growth response of tef (Eragrostis Tef (Zucc.) Trotter) to foliar spray of paclobutrazol was investigated under sub-humid and hot tropical conditions of eastern Ethiopia. At both locations, paclobutrazol was applied at tillering, jointing or panicle emergence stage at rates of $0,1,2$, and $3 \mathrm{~kg}$ a.i. per ha. The results of the field trials demonstrated that paclobutrazol treatment increased leaf chlorophyll $a$ and $b$ content, reduced the rate of leaf transpiration, and increased photosynthetic efficiency that has a direct effect on the productivity of the tef crop. Paclobutrazol treatment had reduced plant height and total leaf area there by reduced excessive vegetative growth and lodging percentage. Paclobutrazol treatment resulted in increased number of fertile tillers, number of fertile florets per spike, and thousand seed mass there by increasing tef grain yield. It is reasonable to point out that paclobutrazol is a potential plant growth regulator for use as a height-shortening anti-lodging agent in tef with subsequent grain yield benefits. Application of $1 \mathrm{~kg}$ a.i. paclobutrazol per hectare seems to be optimum rate and the appropriate stage of application appeared to be between tillering and jointing.
\end{abstract}

Keywords: Eragrostis Tef; Grain Yield; Lodging; Paclobutrazol; Tef

\section{Introduction}

Tef (Eragrostis tef (Zucc.) Trotter) is a $\mathrm{C}_{4}$ tropical cereal (Seyfu, 1997). Ethiopia is the center of origin and diversity (Vavilov, 1951). It is cultivated as a major cereal representing about 20\% $\left(2 \times 10^{6} \mathrm{mt}\right)$ of the gross cereal production (CSA, 1997). Tef production in Ethiopia is characterized by low productivity and the national average yield is about 8.5 quintals per hectare (CSA, 1997). Lodging is one of the bottleneck problems accountable for such low yield. The problem is more serious in areas subjected to high rainfall and strong winds, particularly under growing conditions favorable for its growth and yield. Seyfu (1983) reported that 17 to $23 \%$ yield reduction of improved tef varieties is due to natural lodging. In lodged crop, light utilization is insufficient which results in poor grain filling and reduced yield (Davis and Curry, 1991). Furthermore, lodging reduces the efficiency of manual and mechanical harvesting operations.

Paclobutrazol [(2R, 3R+2S, 3S)-1-(4-chloro-phenyl) 4,4-dimethyl-2-(1,2,4-triazol-1-yl)-pentan-3-ol] (PBZ) is a broad spectrum Gibberellin (GA) biosynthesis inhibitor that belongs to triazole plant growth regulator group (Davis and Curry, 1991). The primary mode of action of PBZ is inhibition of GA biosynthesis by interfering with the ent-kaurene oxidase, which catalyzes the sequential oxidations from ent-kaurene to ent-kaurenoic acid (Rademacher, 1997). One of the most important uses of plant growth retardants is lodging control and widely used in wheat, rice, rye and barley (Davis and Curry, 1991). Properly timed applications of PBZ have been reported to reduce lodging and increase yield in several agronomic crops including ryegrass
(Young et al., 1996), rice (Street et al., 1986) and wheat (Froggatt et al., 1982).

Under Ethiopian conditions, plant growth regulators as means of controlling lodging problem have not been used. However, greenhouse and field experiments were undertaken to investigate the efficacy of 2-chloroethyl trimethylammonium chloride (CCC) to reduce lodging problem and promising results have been observed (Kifle, 1985). Similarly, Kebebew (1991) reported that PBZ is an effective plant growth regulator to control lodging and improve yield in tef. The response of plants to the growth regulators depends on species, cultivar, dose, method and time of application (Davis and Curry, 1991). In this paper, the results of the effect of different rates and time of PBZ application on growth, net photosynthesis, rate of transpiration, lodging, and yield and yield components of tef grown under sub-humid and hot tropical conditions of eastern Ethiopia are presented.

\section{Materials and Methods 2.1. Experimental Site}

The experiment was established at two locations, namely, Haramaya and Dire Dawa, both situated in the semi-arid and arid tropical belt of eastern Ethiopia, during the 2003 cropping season. Haramaya is located at $42^{\circ} 3^{\prime} \mathrm{E}, 9^{\circ} 26^{\prime} \mathrm{N}$, at an altitude of 1980 m.a.s.l, and characterized as having sub-humid type of climate with average annual rainfall of about $790 \mathrm{~mm}$ with a variation between $575 \mathrm{~mm}$ and $1017 \mathrm{~mm}$. The mean annual temperature of Alemaya is about $17{ }^{\circ} \mathrm{C}$ with mean minimum and maximum temperatures of $3.8^{\circ} \mathrm{C}$ and $25{ }^{\circ} \mathrm{C}$, respectively. During the study period, the mean maximum temperature was 26 ${ }^{\circ} \mathrm{C}$ and minimum temperature of $11.4{ }^{\circ} \mathrm{C}$. During the 
growing period a total of $177 \mathrm{~mm}$ precipitation was received and supplementary irrigation was applied. Mean sunshine hours were 9.7 per day, along with a relative humidity of $41 \%$. The soil on which the experiment was conducted is a well-drained deep alluvial soil with 1.38

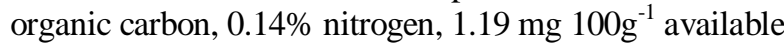
phosphorus, $470 \mathrm{ppm}$ total potassium, and $\mathrm{pH}$ of 7.2.

Dire Dawa is characterized by hot tropical climate and located at $41^{\circ} 50.4^{\prime} \mathrm{E}, 09^{\circ} 36^{\prime} \mathrm{N}$, at an altitude of 1176 m.a.s.l. During the growing period the total precipitation was $230 \mathrm{~mm}$ and supplemental irrigation was applied. The mean monthly minimum and maximum temperatures were $18{ }^{\circ} \mathrm{C}$ and $31{ }^{\circ} \mathrm{C}$, respectively. The mean relative humidity was $50 \%$ with its variation from $20 \%$ to $81 \%$. The soil of the experimental site is a welldrained deep clay loam with $2.36 \%$ organic matter, $1.36 \%$ organic carbon, $0.12 \%$ total nitrogen, $14.15 \mathrm{ppm}$ phosphorus, 1.08 meq100 $\mathrm{gm}^{-1}$ exchangeable potassium, $0.533 \mathrm{mmhoscm}^{-1}$ electrical conductivity and a $\mathrm{pH}$ of 8.6.

\subsection{Variety Used}

The variety used was DZ-01-196. According to Hailu et al. (1995) it has fairly loose type of panicle with branches arranged multilaterally. Depending on the growing condition plant height ranges from $50-117 \mathrm{~cm}$, the average being $82 \mathrm{~cm}$. It is relatively late maturing variety that matures within 80-113 days after planting depending on the growing conditions. Due to its tallness, under favorable growing conditions it is found to be susceptible to lodging.

\subsection{Experimental Design and Plant Culture}

At both locations, treatments were laid down in two factor factorial experiments arranged in randomized complete block design replicated three times. Plots $\left(2 \mathrm{~m}^{2}\right)$ were divided into 5 rows with inter-row spacing of 20 $\mathrm{cm}$. Seeds were broadcasted within each row at a rate of $4.4 \mathrm{~g} \mathrm{pot}^{-1}\left(22 \mathrm{~kg} \mathrm{ha}^{-1}\right)$. After uniform emergence plants were thinned to intra-row spacing of $5 \mathrm{~cm}$ to maintain approximately 100 plants per plot. Phosphorus was applied during planting at a rate of $125 \mathrm{~kg} \mathrm{ha}^{-1}$ in the form of DAP, and after thinning nitrogen was applied (topdressing) at a rate of $100 \mathrm{~kg} \mathrm{ha}^{-1}$ in the form of Urea.

After good establishment, the main stem of five randomly selected plants from each of the three central rows were tagged and relevant data measurements were done on these selected plants. All the required cultural practices were applied as per the recommendations of Seyfu (1987).

\subsection{Treatments}

At three distinct growth stages plants were treated with $\mathrm{PBZ}$ at rates of $0,1,2$ and $3 \mathrm{~kg}$ a.i. $\mathrm{PBZ} \mathrm{ha} \mathrm{ha}^{-1}$ as a foliar application using Cultar formulation (250 g a.i. PBZ per 1, Zeneca Agrochemicals SA (PTY.) LTD., South Africa). A given PBZ concentration was diluted in distilled water $\left(50 \mathrm{ml} \mathrm{plot}^{-1}\right)$ and the aqueous solution was applied uniformly to each plant as fine foliar spray using an atomizer. The control plants were treated with distilled water of equal volume.

\subsection{Stage of Applications}

The following three growth stages were selected on the basis of growth stages identified by Kebebew (1991).

1. Tillering: Thirty days after planting and the plants had an average of four developed leaves on the main stem.

2. Jointing: Forty-five days after planting. The plants had developed about five leaves on the main stem and the second node on the main culm of the plant was detectable.

3. Panicle emergence: Fifty-three days after planting: The plants had developed the maximum leaves ( 6 or more) on the main stem and the emergence of the tips of the panicle through the flag leaf sheath was manifested.

At Dire Dawa, due to higher growing temperature plants grew faster and reached the application stages earlier than the plants grown at Haramaya where there was relatively cool weather. Hence, the application stages were adjusted accordingly.

\subsection{Data Recorded}

Two weeks after the application of the last treatment stomatal conductance, rate of transpiration and photosynthesis were measured using a portable LCA4 photosynthesis system (ADC Bio Scientific Ltd., UK) and leaf chlorophyll content was determined. The measurements were made on three randomly selected tagged plants on the middle portion of the flag leaf. A crude chlorophyll extract was made using $80 \%$ acetone from leaf tissue taken from the mid portion of the flag leaf. Spectrophotometer (Pharmacia LKB, Ultrospec III) readings were taken at 663 and $645 \mathrm{~nm}$ and the concentration of chlorophyll $a$ and $b$ were assessed using the specific absorption coefficients given by Mac Kinney (1941).

Days to panicle emergence refers to the number of days elapsed from planting to the date when $50 \%$ of the plants depicted the emergence of the tips of the panicle. Days to maturity was recorded when $50 \%$ of the plants within a plot change the entire plant color from green to light yellow. Lodging index was determined using the degree of lodging on 0-5 scale according to Caldicott and Nuttall (1979), where 0 value is fully upright $\left(90^{\circ}\right)$ and 5 equals to fully lodged.

Plant height is the length of the main shoot from the base of the main shoot to the apex of its panicle. Panicle length is the length of the panicle of the main shoot from the base to its tip. Culm length is the length from the base of the main shoot culm to the base of the panicle. Internode length refers to the average node length of each of the main shoot culm nodes. Flag leaf length and width refer to the length and the width at the broadest point of the flag leaf blade at maturity. Total leaf area is the total leaf surface area of a plant and measured with a portable 
CI-202 leaf area meter (CID Inc., Vancouver, Washington state, USA). Total biomass refers to dry mass of the crop (above ground and root dry mass) dried at $72{ }^{\circ} \mathrm{C}$ to a constant mass.Number of florets is the total count of grain bearing florets per spiklet. Grain yield per plant is air-dried grain mass harvested from individual plant. Thousand-kernel weight is mass of 1000 tef grains.

\subsection{Statistical Analysis}

The analyses of variance were carried out using MSTATC statistical software (MSTAT-C, 1991). Combined analysis of variance showed significant treatments by site interactions and hence, for all of the parameters considered, the data of the two experiments were presented separately. Means were compared using Least Significant Differences (LSD) test at 5\% probability level. Correlations between parameters were computed where applicable.

\section{Results}

\subsection{Haramaya}

Significant interactions between stage and rate of PBZ application were observed with respect to plant height and culm length, panicle and flag leaf length and leaf area of tef grown at Haramaya ( Table 1 )

Table 1. The interaction effect of stage and rate of PBZ application on plant height and culm length, panicle and flag leaf length, and leaf area of tef grown at Haramaya

\begin{tabular}{llllllll}
\cline { 2 - 5 } \multicolumn{2}{l}{ PBZ application } & \multicolumn{3}{c|}{ Height $(\mathrm{cm})$} & \multicolumn{2}{c}{ Length $(\mathrm{cm})$} & $\begin{array}{l}\text { Leaf area } \\
\left(\mathrm{cm}^{2}\right)\end{array}$ \\
\hline Stage & $\begin{array}{l}\text { Rate }(\mathrm{kg} \\
\left.\text { a.i.PBZ ha }{ }^{-1}\right)\end{array}$ & Crop & Stem & Panicle & Flag leaf & \\
\hline Tillering & 0 (control) & $97.4 \mathrm{a}$ & $48.1 \mathrm{a}$ & $49.3 \mathrm{a}$ & $28.9 \mathrm{a}$ & $380 \mathrm{a}$ \\
& 1 & $56.2 \mathrm{de}$ & $17.8 \mathrm{~cd}$ & $38.4 \mathrm{~d}$ & $12.8 \mathrm{de}$ & $247 \mathrm{de}$ \\
& 2 & $49.5 \mathrm{e}$ & $17.2 \mathrm{~cd}$ & $32.3 \mathrm{e}$ & $9.0 \mathrm{ef}$ & $231 \mathrm{e}$ \\
& 3 & $49.2 \mathrm{ef}$ & $15.6 \mathrm{~d}$ & $33.6 \mathrm{e}$ & $8.2 \mathrm{f}$ & $223 \mathrm{e}$ \\
Jointing & 0 (control) & $98.7 \mathrm{a}$ & $49.3 \mathrm{a}$ & $49.4 \mathrm{a}$ & $28.5 \mathrm{a}$ & $371 \mathrm{a}$ \\
& 1 & $64.1 \mathrm{c}$ & $22.4 \mathrm{c}$ & $41.7 \mathrm{~cd}$ & $15.2 \mathrm{~cd}$ & $290 \mathrm{bc}$ \\
& 2 & $57.3 \mathrm{de}$ & $17.9 \mathrm{~cd}$ & $39.3 \mathrm{~cd}$ & $13.1 \mathrm{de}$ & $287 \mathrm{bc}$ \\
& 3 & $53.8 \mathrm{ef}$ & $18.9 \mathrm{~cd}$ & $34.9 \mathrm{e}$ & $12.1 \mathrm{def}$ & $262 \mathrm{~cd}$ \\
Panicle & 0 (control) & $99.9 \mathrm{a}$ & $49.1 \mathrm{a}$ & $50.8 \mathrm{a}$ & $28.1 \mathrm{a}$ & $377 \mathrm{a}$ \\
emergence & & & & & & \\
& 1 & $82.5 \mathrm{~b}$ & $37.4 \mathrm{~b}$ & $45.1 \mathrm{~b}$ & $20.4 \mathrm{~b}$ & $296 \mathrm{~b}$ \\
& 2 & $62.4 \mathrm{~cd}$ & $19.7 \mathrm{~cd}$ & $42.7 \mathrm{bc}$ & $19.2 \mathrm{bc}$ & $276 \mathrm{bc}$ \\
SEM & 3 & $59.3 \mathrm{~cd}$ & $18.5 \mathrm{~cd}$ & $40.8 \mathrm{bc}$ & $19.1 \mathrm{bc}$ & $266 \mathrm{bc}$ \\
& & 1.62 & 1.54 & 0.85 & 1.11 & 7.70 \\
& & & & & \\
\hline
\end{tabular}

SEM: Stand error of the mean

Means within the same column sharing the same letters are not significantly different at $P<0.05$

At all stages of application, PBZ significantly reduced plant height with no significant difference between the moderate and higher rates. Irrespective of the concentration of PBZ applied, it reduced culm length by about $65 \%$ and $60 \%$ during early tillering and jointing stage, respectively. On the other hand, applying $1 \mathrm{~kg}$ a.i. PBZ ha $^{-1}$ reduced culm length by about $24 \%$ while applying 2 or $3 \mathrm{~kg}$ a.i. PBZ ha ${ }^{-1}$ brought about $61 \%$ culm length reduction when applied during panicle emergence. PBZ treatment reduced flag leaf length by about $65 \%$, $53 \%$, and $30 \%$ when applied at tillering, jointing and panicle emergence, respectively. Panicle length was reduced by about $29 \%, 22 \%$, and $15 \%$ in response to PBZ treatment at tillering, jointing and panicle emergence, respectively. Although not consistent PBZ reduced total leaf area irrespective of the stage and rate of application.

Both stage and concentration of PBZ treatment significantly influenced mean node length, leaf stomatal conductance, rate of transpiration, net photosynthesis, total biomass, number of fertile florets, grain yield, and thousand seed mass tef grown at Haramaya(Table2) 
Table 2. The effect of stage and rate of PBZ application on mean node length, leaf stomatal conductance $\left(\mathrm{g}_{\mathrm{s}}\right)$, rate of transpiration $(\mathrm{T})$, net photosynthesis $\left(\mathrm{P}_{\mathrm{n}}\right)$, total biomass, number of fertile floret, grain yield per plant, thousand seed mass (TSM), and lodging percentage of tef grown at Haramaya

\begin{tabular}{|c|c|c|c|c|c|c|c|c|c|}
\hline Main effect & $\begin{array}{l}\text { Node } \\
\text { length } \\
(\mathrm{cm})\end{array}$ & $\begin{array}{l}\mathrm{g}_{\mathrm{s}} \\
\left(\mathrm{molm}^{-2} \mathrm{~s}^{-1}\right)\end{array}$ & $\begin{array}{l}\mathrm{T} \\
\left(\operatorname{molm}^{-2} \mathrm{~s}^{-1}\right)\end{array}$ & $\begin{array}{l}\mathrm{P}_{\mathrm{n}} \\
\left(\mu \mathrm{molm}^{-2} \mathrm{~s}^{-1}\right)\end{array}$ & $\begin{array}{l}\text { Total } \\
\text { biomass }\end{array}$ & $\begin{array}{l}\text { No. } \\
\text { fertile } \\
\text { floret }\end{array}$ & $\begin{array}{l}\text { Grain } \\
\text { yield }(g)\end{array}$ & $\begin{array}{l}\text { TSM } \\
(\mathrm{mg})\end{array}$ & $\begin{array}{l}\text { Lodging } \\
(\%)\end{array}$ \\
\hline Tillering & $6.8 \mathrm{~b}$ & $0.09 b$ & $1.97 \mathrm{~b}$ & $3.02 \mathrm{c}$ & $16.2 \mathrm{c}$ & $456.9 \mathrm{~b}$ & $6.6 \mathrm{a}$ & $338.3 a$ & $51.41 \mathrm{c}$ \\
\hline Jointing & $7.9 \mathrm{a}$ & $0.11 b$ & $1.99 b$ & $2.25 \mathrm{~b}$ & $17.0 \mathrm{~b}$ & $541.6 \mathrm{a}$ & $6.7 \mathrm{a}$ & $341.7 \mathrm{a}$ & $56.27 \mathrm{~b}$ \\
\hline $\begin{array}{l}\text { Panicle } \\
\text { emerg. }\end{array}$ & $8.6 a$ & $0.19 \mathrm{a}$ & $2.66 \mathrm{a}$ & $3.49 \mathrm{a}$ & $18.3 \mathrm{a}$ & $518.6 \mathrm{a}$ & $6.3 b$ & $329.8 b$ & $60.02 a$ \\
\hline SEM & 0.32 & 0.001 & 0.01 & 0.005 & 0.18 & 13.6 & 0.07 & 1.97 & 1.07 \\
\hline 0 (control) & $12.2 \mathrm{a}$ & $0.15 a$ & $2.57 \mathrm{a}$ & $2.81 \mathrm{~d}$ & $20.6 a$ & $467.7 \mathrm{c}$ & $5.9 \mathrm{c}$ & $323.0 \mathrm{c}$ & $89.31 \mathrm{a}$ \\
\hline $1 \mathrm{~kg} \mathrm{PBZ}$ & $7.0 \mathrm{~b}$ & $0.13 \mathrm{ab}$ & $2.23 b$ & $3.29 \mathrm{c}$ & $16.8 b$ & $517.6 \mathrm{~b}$ & $6.6 \mathrm{~b}$ & $335.4 \mathrm{~b}$ & $48.40 \mathrm{~b}$ \\
\hline $2 \mathrm{~kg}$ PBZ & $5.9 \mathrm{~b}$ & $0.12 \mathrm{ab}$ & $2.12 \mathrm{c}$ & $3.38 b$ & $16.1 \mathrm{c}$ & $521.7 \mathrm{a}$ & $6.8 \mathrm{a}$ & $343.1 \mathrm{ab}$ & $44.80 \mathrm{c}$ \\
\hline $3 \mathrm{~kg}$ PBZ & $5.8 \mathrm{~b}$ & $0.11 \mathrm{~b}$ & $1.91 d$ & $3.54 \mathrm{a}$ & $15.2 \mathrm{~d}$ & $515.8 \mathrm{ab}$ & $6.7 \mathrm{ab}$ & $344.9 \mathrm{a}$ & $41.20 \mathrm{~d}$ \\
\hline SEM & 0.37 & 0.001 & 0.01 & 0.006 & 0.20 & 15.8 & 0.08 & 2.27 & \\
\hline
\end{tabular}

SEM: Stand error of the mean

Means within the same column (with in the same main effect) sharing the same letters are not significantly different $(P<0.05)$

Applying PBZ at early tiller development significantly reduced node length than applying during early joint and panicle emergence. Regardless of the rate, PBZ application reduced mean node length by about $50 \%$ as compared to the check.

Early and mid application of PBZ significantly reduced stomatal conductance and reduced rate of leaf transpiration than late application. Means pooled over stage of application showed that regardless of the concentration, applied PBZ reduced stomatal conductance by $21 \%$. PBZ significantly reduced rate of leaf transpiration and there was a tendency of reducing the rate with increasing concentration. Stage of application remarkably influenced leaf net photosynthesis in such a way that late treated plants exhibited an increased rate followed by mid and early treatment. Application of $1 \mathrm{~kg}$ a.i. $\mathrm{PBZ} \mathrm{ha} \mathrm{H}^{-1}$ increased rate of net photosynthesis by $17 \%, 2 \mathrm{~kg}$ by $20 \%$ and $3 \mathrm{~kg}$ by $26 \%$ over the control.

With respect to total biomass production PBZ had strong reduction effect when applied during early tiller development followed by jointing and panicle emergence. Applying 1, 2, and $3 \mathrm{~kg}$ a.i. $\mathrm{PBZ} \mathrm{ha}^{-1}$ resulted in approximately $18 \%, 22 \%$, and $26 \%$ biomass reduction respectively, as compared to the control. PBZ increased number of fertile floret per plants when applied at early jointing (542) and panicle emergence (519) in contrast to early tiller development (457). PBZ treatment brought about $11 \%$ fertile florets increment over the control. Applying PBZ during early tillering and jointing stage gave higher grain yield than late application. PBZ application at a rate of $1 \mathrm{~kg}$ a.i. $\mathrm{ha}^{-1}$ increased grain yield by about $12 \%$ while applying 2 or $3 \mathrm{~kg}$ gave $14.4 \%$ advantage as compared to the control. Similarly, the two early PBZ applications showed higher thousands seed mass than the late treatment. As compared to the control, application of $1 \mathrm{~kg}$ a.i. PBZ ha ${ }^{-1}$ increased thousand seed mass by about $4 \%$ while treatment with 2 or $3 \mathrm{~kg}$ PBZ increased by about $7 \%$.

PBZ concentration significantly influenced days to panicle emergence and maturity, flag tef width, leaf chlorophyll content, number of fertile and total tillers of tef grown in a sub-humid growing condition.(Table 3 )

Table 3. The effect of PBZ concentration on days to panicle emergence and maturity, flag leaf width, leaf chlorophyll $a$ and chlorophyll $b$ content, number of fertile, unfertile and total tillers of tef grown at Haramaya

\begin{tabular}{|c|c|c|c|c|c|c|c|c|}
\hline \multirow[t]{2}{*}{$\begin{array}{l}\text { Rate }(\mathrm{kg} \text { a.i. } \\
\left.\text { PBZ }^{-1}{ }^{-1}\right)\end{array}$} & \multirow{2}{*}{$\begin{array}{l}\text { Days to } \\
\text { panicle } \\
\text { emerg. }\end{array}$} & \multirow[t]{2}{*}{$\begin{array}{l}\text { Days to } \\
\text { maturity }\end{array}$} & \multirow[t]{2}{*}{$\begin{array}{l}\text { Flag leaf } \\
\text { width }(\mathrm{mm})\end{array}$} & \multicolumn{2}{|c|}{$\begin{array}{l}\text { Chlorophyll content } \\
\left(\mathrm{mg} \mathrm{g}^{-1} \mathrm{FW}\right)\end{array}$} & \multicolumn{3}{|c|}{ Tiller number } \\
\hline & & & & $a$ & $b$ & Fertile & Unfertile & Total \\
\hline 0 (control) & $54.2 b$ & $100.8 \mathrm{~b}$ & $64.6 \mathrm{a}$ & $1.30 \mathrm{~b}$ & $0.32 b$ & $8.2 b$ & $2.4 \mathrm{a}$ & $10.5 b$ \\
\hline 1 & $65.3 a$ & $107.4 \mathrm{a}$ & $61.7 b$ & $1.50 \mathrm{a}$ & $0.41 \mathrm{a}$ & $12.7 \mathrm{a}$ & $2.2 \mathrm{a}$ & $14.9 \mathrm{a}$ \\
\hline 2 & $64.4 \mathrm{a}$ & $108.1 \mathrm{a}$ & $61.0 \mathrm{~b}$ & $1.57 \mathrm{a}$ & $0.46 \mathrm{a}$ & $13.2 \mathrm{a}$ & $2.9 \mathrm{a}$ & $16.12 \mathrm{a}$ \\
\hline 3 & $64.0 \mathrm{a}$ & $108.9 \mathrm{a}$ & $60.4 b$ & $1.53 \mathrm{a}$ & $0.40 \mathrm{a}$ & $12.5 \mathrm{a}$ & $2.6 \mathrm{a}$ & $15.11 \mathrm{a}$ \\
\hline SEM & 0.91 & 0.74 & 0.52 & 0.05 & 0.24 & 0.31 & 0.18 & 0.32 \\
\hline
\end{tabular}

SEM: Stand error of the mean

Means within the same column sharing the same letters are not significantly different $(P<0.05)$ 
At all rates PBZ treatment delayed days required to panicle emergence and maturity by about 10 and 7 days, respectively. Irrespective of the rates of application, PBZ increased leaf chlorophyll $a$ by $18 \%$ and chlorophyll $b$ by $32 \%$ as compared to the check. PBZ significantly increased the number of fertile and total tillers while the number of unfertile tillers unaffected. Regardless of the concentration, the number of fertile and total tillers increased by about $56 \%$ and $46 \%$, respectively, in response to PBZ treatment.
The interaction effect of stage and rate of PBZ application on plant height and culm, panicle, node and flag leaf length, of tef grown at Dire Dawa is presented in table 4. Both stage and rate of PBZ application significantly affected total leaf area, chlorophyll $a$ and chlorophyll $b$, stomatal conductance, rate of transpiration, net hotosynthesis, total biomass, number of fertile floret, grain yield, thousand seed mass and lodging percentile of tef grown under hot tropical climate ( Table 5 ).

\subsection{Dire Dawa}

Table 4. The interaction effect of stage and rate of PBZ application on plant height and culm length, panicle, node and flag leaf length, of tef grown at Dire Dawa

\begin{tabular}{|c|c|c|c|c|c|c|}
\hline \multicolumn{2}{|c|}{ PBZ application } & \multicolumn{2}{|c|}{ Height $(\mathrm{cm})$} & \multicolumn{3}{|c|}{ Length $(\mathrm{cm})$} \\
\hline Stage & Rate $\left(\mathrm{kg}\right.$ a.i. $\left.\mathrm{PBZ} \mathrm{ha}^{-1}\right)$ & Crop & Stem & Panicle & Node & Flag leaf \\
\hline \multirow[t]{4}{*}{ Tillering } & 0 (control) & $105.6 \mathrm{a}$ & $52.8 \mathrm{a}$ & $52.9 \mathrm{a}$ & $13.8 \mathrm{a}$ & $31.8 \mathrm{a}$ \\
\hline & 1 & 63.1def & $22.5 \mathrm{~cd}$ & 40.6de & $7.8 \mathrm{~cd}$ & $14.1 \mathrm{de}$ \\
\hline & 2 & $56.2 \mathrm{f}$ & $21.9 \mathrm{~cd}$ & $34.3 \mathrm{f}$ & $5.4 \mathrm{~g}$ & $9.9 \mathrm{ef}$ \\
\hline & 3 & $55.9 \mathrm{f}$ & $20.3 d$ & $35.6 \mathrm{f}$ & $5.2 \mathrm{~g}$ & $9.1 \mathrm{f}$ \\
\hline \multirow[t]{4}{*}{ Jointing } & 0 (control) & $106.9 \mathrm{a}$ & $53.9 \mathrm{a}$ & $52.9 \mathrm{a}$ & $13.0 \mathrm{a}$ & $31.4 \mathrm{a}$ \\
\hline & 1 & $71.2 \mathrm{c}$ & $27.1 \mathrm{c}$ & $44.2 \mathrm{~cd}$ & $7.5 \mathrm{~d}$ & $16.8 \mathrm{~cd}$ \\
\hline & 2 & $64.1 \mathrm{cde}$ & $22.6 \mathrm{~cd}$ & $41.5 \mathrm{~cd}$ & $6.8 \mathrm{ef}$ & $14.5 \mathrm{de}$ \\
\hline & 3 & $60.6 \mathrm{ef}$ & $23.5 \mathrm{~cd}$ & 37.1ef & $6.2 \mathrm{f}$ & $13.3 \mathrm{def}$ \\
\hline \multirow{4}{*}{$\begin{array}{l}\text { Panicle } \\
\text { emergence }\end{array}$} & 0 (control) & $108.5 \mathrm{a}$ & $53.9 \mathrm{a}$ & $54.6 \mathrm{a}$ & $13.5 \mathrm{a}$ & $31.0 \mathrm{a}$ \\
\hline & 1 & $90.4 b$ & $42.1 b$ & $48.3 b$ & $10.2 b$ & $22.5 b$ \\
\hline & 2 & $69.4 \mathrm{~cd}$ & $24.4 \mathrm{~cd}$ & $45.0 \mathrm{bc}$ & $8.2 \mathrm{c}$ & $21.2 b$ \\
\hline & 3 & $66.2 \mathrm{~cd}$ & $23.2 \mathrm{~cd}$ & $43.0 \mathrm{~cd}$ & $7.2 \mathrm{de}$ & $21.1 \mathrm{bc}$ \\
\hline SEM & & 1.83 & 1.54 & 1.02 & 0.05 & 1.21 \\
\hline
\end{tabular}

SEM: Stand error of the mean

Means within the same column sharing the same letters are not significantly different $(P<0.05)$

Table 5. The effect of stage and rate of PBZ application on leaf area, chlorophyll a, chlorophyll $b$, stomatal conductance $\left(\mathrm{g}_{\mathrm{s}}\right)$, rate of transpiration $(\mathrm{T})$, net photosynthesis $\left(\mathrm{P}_{\mathrm{n}}\right)$, total biomass, number of fertile florets, grain yield, thousand seed mass (TSM), and lodging percentage of tef grown at Dire Dawa

\begin{tabular}{|c|c|c|c|c|c|c|c|c|c|c|c|}
\hline \multirow[t]{2}{*}{ Main effect } & \multirow{2}{*}{$\begin{array}{l}\text { Leaf } \\
\text { area } \\
\left(\mathrm{cm}^{2}\right)\end{array}$} & \multicolumn{2}{|c|}{$\begin{array}{l}\text { Chlorophyll } \\
\left(\mathrm{mg} \mathrm{g}^{-1} \mathrm{FW}\right)\end{array}$} & \multirow[t]{2}{*}{ 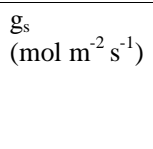 } & \multirow{2}{*}{$\begin{array}{l}\mathrm{T} \\
(\mathrm{mol} \\
\left.\mathrm{m}^{-2} \mathrm{~s}^{1}\right)\end{array}$} & \multirow{2}{*}{$\begin{array}{l}P_{n} \\
(\mu \mathrm{mol} \\
\left.\mathrm{m}^{-2} \mathrm{~s}^{-1}\right)\end{array}$} & \multirow[t]{2}{*}{$\begin{array}{l}\text { Total } \\
\text { biomass }\end{array}$} & \multirow{2}{*}{$\begin{array}{l}\text { No. } \\
\text { fertile } \\
\text { floret }\end{array}$} & \multirow{2}{*}{$\begin{array}{l}\text { Grain } \\
\text { yield } \\
\text { (g) }\end{array}$} & \multirow[t]{2}{*}{$\begin{array}{l}\text { TSM } \\
(\mathrm{g})\end{array}$} & \multirow[t]{2}{*}{$\begin{array}{l}\text { Lodgin } \\
\mathrm{g}(\%)\end{array}$} \\
\hline & & $a$ & $b$ & & & & & & & & \\
\hline Tillering & $277.3 b$ & $1.44 \mathrm{~b}$ & $0.38 b$ & $0.10 \mathrm{~b}$ & $2.01 \mathrm{~b}$ & $3.32 \mathrm{c}$ & $17.1 \mathrm{~b}$ & $427.9 b$ & $6.4 \mathrm{a}$ & $347.5 \mathrm{a}$ & $53.57 \mathrm{c}$ \\
\hline Jointing & $310.9 a$ & $1.46 \mathrm{a}$ & $0.38 b$ & $0.13 b$ & $2.04 \mathrm{~b}$ & $3.58 \mathrm{~b}$ & $17.8 b$ & $498.5 a$ & $6.5 \mathrm{a}$ & $350.8 \mathrm{a}$ & $58.47 \mathrm{~b}$ \\
\hline $\begin{array}{l}\text { Panicle } \\
\text { emerg. }\end{array}$ & $311.6 \mathrm{a}$ & $1.46 \mathrm{a}$ & $0.45 a$ & $0.22 \mathrm{a}$ & $2.73 \mathrm{a}$ & $3.83 a$ & $19.4 \mathrm{a}$ & $474.3 \mathrm{a}$ & $6.1 b$ & $338.6 b$ & $63.22 \mathrm{a}$ \\
\hline SEM & 5.10 & 0.001 & 0.001 & 0.001 & 0.02 & 0.001 & 0.19 & 10.9 & 0.07 & 2.02 & 1.53 \\
\hline 0 (control) & $386.2 \mathrm{a}$ & $1.31 \mathrm{~d}$ & $0.33 \mathrm{c}$ & $0.18 \mathrm{a}$ & $2.63 a$ & $3.10 \mathrm{~d}$ & $21.7 \mathrm{a}$ & $430.0 \mathrm{~b}$ & $5.8 b$ & $331.6 \mathrm{c}$ & $94.18 \mathrm{a}$ \\
\hline $1 \mathrm{~kg}$ PBZ & $285.1 \mathrm{~b}$ & $1.52 b$ & $0.38 b$ & $0.15 a b$ & $2.28 \mathrm{~b}$ & $3.61 \mathrm{c}$ & $17.9 \mathrm{~b}$ & $482.6 a$ & $6.4 \mathrm{a}$ & $344.3 b$ & $50.27 \mathrm{~b}$ \\
\hline 2 kg PBZ & $271.6 \mathrm{bc}$ & $1.56 \mathrm{a}$ & $0.44 a$ & $0.14 b$ & $2.17 \mathrm{c}$ & $3.71 b$ & $16.9 \mathrm{c}$ & $483.4 \mathrm{a}$ & $6.7 \mathrm{a}$ & $352.4 \mathrm{ab}$ & $46.55 \mathrm{c}$ \\
\hline 3 kg PBZ & $257.1 \mathrm{c}$ & $1.44 c$ & $0.46 a$ & $0.13 b$ & $1.96 \mathrm{~d}$ & $3.89 a$ & $15.9 \mathrm{~d}$ & $471.5 \mathrm{a}$ & $6.5 \mathrm{a}$ & $354.2 \mathrm{a}$ & $42.68 \mathrm{~d}$ \\
\hline SEM & 8.84 & 0.002 & 0.001 & 0.001 & 0.02 & 0.01 & 0.21 & 12.6 & 0.08 & 2.34 & 1.78 \\
\hline
\end{tabular}

SEM: Stand error of the mean

Means within the same column (with in the same main effect) sharing the same letters are not significantly different $(P<0.05)$ 
The application of PBZ at early stage (tillering) reduced total leaf area than applying at jointing and panicle emergence. Applying $1 \mathrm{~kg}$ a.i. $\mathrm{PBZ} \mathrm{ha} \mathrm{h}^{-1}$ reduced total leaf area by about $26 \%$ and 2 or $3 \mathrm{~kg}$ PBZ resulted in $32 \%$ leaf surface area reduction over the control. Moderate and late application increased chlorophyll $a$ content of the leaf than early application. On the other hand, late PBZ treatment resulted in higher leaf chlorophyll $b$ content than early and moderate application. An increase of 16, 19, and 9\% chlorophyll $a$ content over the control due to the application of $1 \mathrm{~kg}, 2$ $\mathrm{kg}$, and $3 \mathrm{~kg}$ a.i. PBZ ha ${ }^{-1}$, respectively. Similarly, chlorophyll $b$ content was increased by about $15 \%$ in response to $1 \mathrm{~kg}$ a.i. $\mathrm{PBZ} \mathrm{ha}{ }^{-1}$ while application of 2 or 3 $\mathrm{kg}$ resulted in $36 \%$ increment.

Application of PBZ during early tillering and jointing stage reduced stomatal conductance much better than late application. Conversely, higher rate of leaf transpiration was observed during early tillering and jointing than panicle emergence. Regardless of the concentration, PBZ treatment decreased leaf stomatal conductance by about $22 \%$ compared to the control. Concomitantly, application of $1 \mathrm{~kg}, 2 \mathrm{~kg}$, and $3 \mathrm{~kg}$ a.i. $\mathrm{PBZ} \mathrm{ha}{ }^{-1}$ reduced the rate of leaf transpiration by about $13 \%, 17 \%$, and $25 \%$ as compared to the control. Plants treated during panicle emergence showed the highest rate of net photosynthesis, followed by plants treated during early jointing and tillering stage. PBZ treatment at a rate of $1 \mathrm{~kg}$ a.i. ha ${ }^{-1}$ increased net photosynthesis by $17 \%, 2 \mathrm{~kg}$ by $20 \%$ and 3 $\mathrm{kg}$ by $26 \%$ as compared to the control. Significantly higher number of fertile florets was recorded on plants treated during early joint development and panicle emergence stage than plants treated at the tillering stage. PBZ treatment increased the number of fertile florets by about $11 \%$ as compared to the control. Plants that received PBZ treatment during tillering and jointing stage exhibited higher grain yield than those treated at panicle emergence. Yield advantage of about $13 \%$ over the control was achieved due to PBZ treatment. Early application of PBZ significantly reduced lodging percentage than moderate and last application. Application of $1 \mathrm{~kg}, 2 \mathrm{~kg}, 3 \mathrm{~kg}$ a.i PBZ ha ${ }^{-1}$ reduced lodging percentage by about $45 \%, 51 \%$ and $55 \%$ respectively, over the control. Irrespective of the concentration PBZ treatment extended day to panicle emergence and maturity, and reduced flag leaf width. PBZ increased number of fertile and total tillers without affecting the number of unfertile tillers.(Table 6)

Table 6. The effect of PBZ concentration on days to panicle emergence and maturity, flag leaf width, number of fertile, unfertile and total tillers of tef grown at Dire Dawa

\begin{tabular}{|c|c|c|c|c|c|c|}
\hline \multirow{2}{*}{\begin{tabular}{l}
\multicolumn{1}{c}{ Rate } \\
(kg a.i. \\
PBZ ha $\left.{ }^{-1}\right)$
\end{tabular}} & \multirow{2}{*}{$\begin{array}{l}\text { Days to } \\
\text { panicle emerg. }\end{array}$} & \multirow{2}{*}{$\begin{array}{l}\text { Days to } \\
\text { maturity }\end{array}$} & \multirow{2}{*}{$\begin{array}{l}\text { Flag leaf } \\
\text { width }(\mathrm{mm})\end{array}$} & \multicolumn{3}{|c|}{ Tiller number } \\
\hline & & & & Fertile & Unfertile & Total \\
\hline 0 (control) & $49.3 b$ & $91.7 \mathrm{~b}$ & $66.9 \mathrm{a}$ & $8.4 \mathrm{~b}$ & $3.3 \mathrm{a}$ & $11.7 \mathrm{~b}$ \\
\hline 1 & $57.3 \mathrm{a}$ & $98.1 \mathrm{a}$ & $63.9 b$ & $13.1 \mathrm{a}$ & $3.1 \mathrm{a}$ & $16.2 \mathrm{a}$ \\
\hline 2 & $56.8 \mathrm{a}$ & $99.4 \mathrm{a}$ & $63.2 \mathrm{~b}$ & $13.7 \mathrm{a}$ & $3.8 \mathrm{a}$ & $17.5 \mathrm{a}$ \\
\hline 3 & $56.8 \mathrm{a}$ & $100.6 \mathrm{a}$ & $62.7 \mathrm{~b}$ & $12.9 \mathrm{a}$ & $3.5 \mathrm{a}$ & $16.4 \mathrm{a}$ \\
\hline SEM & 0.62 & 0.64 & 0.53 & 0.31 & 0.18 & 0.31 \\
\hline
\end{tabular}

SEM: Stand error of the mean

Means within the same column sharing the same letters are not significantly different at $P<0.05$

\section{Discussion}

PBZ is a potent plant growth regulator and it is required in relatively low concentration to induce physiological, anatomical and morphological changes in plants.

The most striking growth response of tef to PBZ treatment was a reduction in shoot growth. Treated plants appeared to be short and compact due to the reduction in internode length and leaf area. Results of studies on cereals indicated that tallness is strongly associated with endogenous gibberellin content. Nihonbare, a tall rice variety has significantly higher gibberellin content than a semi dwarf variety, Tongil (Takahashi, 1986). Harada (1985) reported that incorporation of a dwarfing gene Dee-geo-woo-gen in rice varieties reduced gibberellin biosynthesis. Moreover, GA treatment increased plant height and encouraged shoot growth in rice (Hanada, 1964; Jung, 1986; Yim et al., 1997). It is speculated that reduced gibberellins biosynthesis in response to $\mathrm{PBZ}$ treatment might have resulted in a reduction in cell proliferation that apparently leads to reduction in stem elongation and leaf expansion. Reduction in the endogenous gibberellin level of wheat was proportional to the concentration of PBZ treatment, and leaf length was correlated linearly to $\log$ concentration of $\mathrm{GA}_{1}$ according to Lenton and Hedden (1987). Yim et al. (1997) reported that PBZ is translocated primarily apoplastically through the xylem to its site of action where it decreases the rate of cell division and elongation, ultimately resulting in reduction in vegetative growth. PBZ treatment effectively reduced plant height in wheat (Froggatt et al., 1982), maize (Shanahan and Nielson, 1987), rice (Yim et al., 1997), cool season grasses such as chewing's fescue and orchard grass (Young et al., 1999), and tef (Kebebew, 1991). 
The remarkable reduction of lodging in tef due to PBZ treatment is attributed to reduction in excessive top growth and plant height. PBZ is more effective in reducing lodging when applied at tillering stage than applying during jointing and panicle emergence. Regardless of the concentration, PBZ sprayed at the end of tillering and early jointing stage significantly reduced lodging in tef (Kebebew, 1991). Guoping (1997) observed that about $30 \%$ of the untreated wheat plants lodged while the PBZ treated plants did not. Properly timed application of PBZ significantly reduced lodging and improved yield in Lolium perenne (Hampton and Hebblethwaite 1985), rice (Street et al., 1986) and wheat (Forgatta et al., 1982).The leaves of PBZ treated plants typically exhibited dark green color compared to the control. This is attributed to an increase in chlorophyll $a$ and $b$ content of the leaves either as the result of enhanced chlorophyll synthesis and/or the presence of more chloroplasts per unit leaf area of treated leaves. The observed negative correlation between total leaf area and chlorophyll $a$ content $(\mathrm{r}=-0.82)$; total leaf area and chlorophyll $b$ content $\left(\mathrm{r}=-0.91^{*}\right)$ at Dire Dawa indicate that the reduction in total leaf area in response to PBZ treatment contributed substantially for chlorophyll $a$ and $b$ increment. Similarly, Yim et al. (1997) reported that PBZ significantly increased leaf chlorophyll content of rice seedlings. Khalil (1995) reported the existence of densely packed chloroplast per unit leaf area of cereals in response to $\mathrm{PBZ}$ treatment.

The higher chlorophyll content of the treated leaves and delayed physiological maturity may be related to the influence of PBZ on endogenous cytokinins content. It has been proposed that PBZ stimulates cytokinin synthesis, which increases chloroplast differentiation and chlorophyll biosynthesis, and prevents chlorophyll degradation (Fletcher et al., 1982). Investigations on rice (Izumi et al., 1988), soybean (Grossmann, 1992) and Dianthus caryophyllus (Sebastian et al., 2002) showed that exogenous application of gibberellin biosynthesis inhibitors increased cytokinin content of the plant tissues. The PBZ treatments significantly reduced the rate of transpiration in tef leaves. This could be due to the partial closure of stomata in response to the treatment as indicated by the concomitant reduction in stomatal conductance. It is postulated that the reduction in stomatal conductance in response to PBZ treatment might have been mediated through its effect on endogenous ABA content (Rademacher, 1997) as ABA is involved in regulating the opening and closing of stomata (Salisbury and Ross, 1992). Asare-Boamah (1986) observed reduction in transpiration, increased diffusive resistance and a transient rise in ABA level in response to triazole treatment. Such a response may improve drought tolerance of the plant to withstand the problem of water deficit whenever there is shortage. PBZ treatment has been shown to reduce water loss and improve water use efficiency in grapevine, chrysanthemum, and beetroot
(Ritchie et al., 1991; Smith et al., 1992; Roberts and Mathews, 1995).

Unlike its effect on the rate of transpiration, PBZ treatment increased photosynthetic efficiency of tef. This response could be linked with the increase in chlorophyll concentration. Sink regulation of photosynthesis is a well-accepted concept, possibly explaining the coordination of assimilate production and utilization (Stitt et al., 1990). There are contradicting reports regarding the effects of $\mathrm{PBZ}$ on rate of photosynthesis. Although PBZ treatment increased chlorophyll concentration, it has little effect on rice photosynthetic efficiency (Yim et al., 1997). On the contrary, an increased net photosynthesis in response to PBZ treatment had been reported in soybean rape (Zhou and $\mathrm{Xi}, 1993$ ) and potato (Tekalign and Hammes, 2005a).

Both at Haramaya and Dire Dawa PBZ treatment increased the number of total and fertile tillers without affecting the number of unfertile tillers. This could be associated with the reduction in endogenous GA levels in response to the treatment. Inhibition of tiller production by exogenous GA treatment has been reported in rice (Jung, 1986; Yim et al.,1997). PBZ treatment stimulated tiller initiation in rice (Yim et al., 1997), wheat (Guoping, 1996), and velvet grass (Hamton et al., 1992).

Yield in tef is the resultant of number of fertile tillers, number of grain per tiller and mass of individual grain. PBZ treatments increased tef grain yield. This is ascribed to an increased number of fertile tillers, number of fertile florets per spiklet, and mass of individual grain. Similar studies indicated that PBZ improved seed yield of chewing's fescue and tall fescue by increasing the number of spikelets per panicle and florets per spikelets, which cumulatively resulted in significant increases in floret sites and the number of seeds produced per unit area (Young et al., 1999). Albeke et al. (1983) reported that PBZ applied either at spikelet initiation or at floret initiation increased number of spikelets per panicle and florets per unit area without affecting number of tillers. Hampton and Hebbleth-waite (1985) reported that the beneficial effect of PBZ on perennial ryegrass seed yield is sometimes attributed to increase in the number of fertile tillers. PBZ did not increase the number of fertile tillers in cool season grasses such as chewing's fescue, tall fescue and orchard grass (Young et al., 1999).

At both sites PBZ treatment significantly reduced total biomass yield. Assimilate partitioning to the different sinks is controlled by environmentally regulated hormonal balances (Almekinders and Struik, 1996). It has been suggested that the inhibition effect of vegetative growth in response to PBZ treatment alters the pattern of assimilate allocation and relative sink strength in favour of grain development. Young et al. (1999) reported that the increase in seed yield of cool season grass species after PBZ treatment may be due to the diversion of more assimilates to the seeds at 
the expense of vegetative tiller formation after anthesis. PBZ increased rye seed yield by reducing stem elongation that can directly compete with the growing spike for assimilates (Clemence and Hebblethwaite, 1985). The involvement of GA in regulating the pattern of assimilate partitioning was suggested by Yim et al. (1997). PBZ increased the partitioning of assimilates to economically important plant parts such as bulbs (De Resende and De Souza, 2002) and tubers (Tekalign and Hammes, 2005a).

Starch is the largest proportion in the carbohydrate fraction of tef grain (Bultosa et al., 2002). An increase in an individual grain mass (as measured in thousand seed mass) may be ascribed to enhanced starch synthesis in response to PBZ treatment. PBZ treatment increased starch accumulation in the leaves, stems, crowns and roots of rice seedling while $\mathrm{GA}_{3}$ treatment decreased starch accumulation in the leaves and crowns of the seedlings (Yim et al., 1997). PBZ treatment increased root starch content in maize (Baluska et al., 1993) and root and stem of potato plants (Tekalign and Hammes, 2005b).

\section{Conclusion}

Field trials at Alemeya and Dire Dawa demonstrated that PBZ treatment increased leaf chlorophyll content, reduced the rate of leaf transpiration, and enhanced the rate of net photosynthesis in tef which have direct effect on its productivity. The treatment had reduced plant height and total leaf area that significantly reduced excessive vegetative growth and lodging percentage. PBZ treatment had increased number of fertile tillers, number of fertile florets per spiklet, and thousand seed mass there by increased tef grain yield. It is reasonable to point out that PBZ is a potential plant growth regulator for use as a height-shortening anti-lodging agent in tef with considerable grain yield benefits. Application of 1 $\mathrm{kg}$ a.i PBZ ha ${ }^{-1}$ seems to be an optimum rate and the appropriate stage of application appeared to be between tillering and jointing. Since the trials were conducted at two locations for one season, it is recommended that these finding must be ascertained by further filed trials to reach to coherent recommendation.

\section{References}

Albeke, D.W., Chilcote, D.O. and Youngberg, H.W. 1983. Chemical dwarfing effect on seed yield of tall fescue (Festuca arundinacea) cv. Fawn, fine fescue (Festuca rubra) cv. Cascade, and Kentucky blue (Poa pratensis) cv. Newport. Journal of Applied Seed Production 1: 39-42.

Almekinders, C.J.M. and Struik, P.C. 1996. Shoot development and flowering in potato (Solanum tuberosum L.). Potato Research 39: 581-607.

Asare-Boamah, N.K., Hofstra, G., Fletcher, R.A. and Dumbroff, E.B. 1986. Triadimefon protects bean plants from water stress through its effects on abscisic acid. Plant Cell Physiology 27: 383-390.

Baluska, F., Parker, J.S. and Barlow, P.W. 1993. A role of gibberellic acid in orienting microtubules and regulating cell polarity in the maize cortex. Planta 191: 149-157.

Bultosa, G., Hall, A.N. and Taylor, J.R.N. 2002. Physico-chemical characterization of grain tef (Eragrostis tef (Zucc.) Troter) starch. Starch/Stärke 54: 461-468.

Caldicott, J.B. and Nuttal, A.M. 1979. A method for the assessment of lodging in cereals crops. $J$. Nation. Inst. Agric. Bot. 15: 18-19.

Clemences, T.G.A. and Hebblehwaite, P.D. 1985. An appraisal of ear, leaf and $\mathrm{stem}^{14} \mathrm{CO}_{2}$ assimilation. ${ }^{14} \mathrm{C}$-assimilate distribution and growth in a reproductive seed crop of amenity Lolium perenne. Annals of Applied Biology 105: 319-327.

CSA (Central Statistical Authority). 1997. Agricultural samples survey, 1996/97. Report on the area and production for the major crops. Private peasant holdings. Statistical Bulletin No. 171, Addis Ababa, Ethiopia

Davis, T.D. and Curry, E.A. 1991. Chemical regulation of vegetative growth. Critical Review in Plant Science 10: 151-188.

De Resende, G.M. and De Souza, R.J. 2002. Effects of paclobutrazol doses on garlic crop. Pesquisa Agropecuária Brasileira 37 (5): 637-641.

Fletcher, R.A., Kallidumbil, V. and Steele, P. 1982. An improved bioassay for cytokinin using cucumber cotyledons. Plant Physiology 69: 675-677.

Froggatt, P.J., Thomas, D.W. and Batch, J.J. 1982. Opportunities for manipulation of cereal productivity. In: Hawkins A J. and Jeffcoat E. (eds.). Recent development in the use of plant growth retardants. British Plant Growth Regulator Group, Wantage. pp. 71-74.

Grossman, K. 1992. Plant growth retardants: Their mode of action and benefit for physiological research. In: Karssen C.M. and Van Loon L.C. and Vreugdenhil D. (eds.). Progress in plant growth regulations. Kluwer Academic Publisher, The Netherlands.

Guoping, Z. 1997. Gibbrellic acid modifies some growth and physiological effects of paclobutrazol (PP333) on wheat. Journal of Plant Growth Regulation 16: 21-25.

Hailu, T., Mulu, A. and Kebebew, A. 1995. Improved varieties of tef (Eragrostis tef) in Ethiopia: Releases of 1970-1995. Research bulletin No. 1, Debrezeit Agricultural Research Center, Ethiopia. 
Hampton, J.G., Tolentino, M.S. and Hill, M.J. 1992. Effect of plant growth regulator on seed yield in velvet grass (Holcus lanatus L.) cv Massey Basyn. New Zealand Journal of Agricultural Research 35: 35-40.

Hampton, J.G. and Hebblethwaite, P.D. 1985. The effect of the growth regulator paclobutrazol (PP333) on the growth, development and yield of Lolium perenne grown for seed. Grass Forage Science 40: 93-101.

Hanada, K. 1964. Studies on branching habits in crop plants. 3. Effects of leaf removal or addition of gibbrellic acid through leaf blade on the growth of tillering buds in rice seedlings. Crop Science Society of Japan 33: 247-254.

Harada, J. 1995. High yielding semi dwarf rice and gibberellins. International seminar on plant growth regulation in agriculture, Tokyo, Japan. pp. $15-20$.

Izumi, K., Nakagawa, S., Kobayashi, M., Oshio, H., Sakurai, A. and Takahashi, N. 1988. Levels of IAA, Cytokinins, ABA and ethylene in rice plants as affected by GA biosynthesis inhibitor, Uniconazole-P. Plant Cell Physiology 29: 97-104.

Jung, J., Rentzea, C. and Rademacher, W. 1986. Plant growth regulation with triazoles of the dioxanyl type. Journal of Plant Growth Regulation 4: 181-188.

Khalil, I.A. 1995. Chlorophyll and carotenoid contents in cereals as affected by growth retardants of the triazole series. Cereal Research Communication 23: 183-189

Kebebew, A. 1991. The effect of ethephone, CCC and paclobutrazol on yield and lodging of tef. MSc. Thesis, Alemaya University, Ethiopia.

Kifle, W. 1985. Some aspects of response of tef (Eragrostis tef (Zucc.) to 2-chloroethyl trimethylammonium chloride (CCC). M.Sc. Thesis, University of London, Wye College. pp. 60.

Le Guen-Le Saos, F., Hourmant, A., Esnault, F. and Chauvin, J.E. 2002. In vitro bulb development in shallot (Allium cepa L. Aggregatum Group): effects of antigibberellins, sucrose and light. Annals of Botany 89: 419-425.

Lenton, J.R. and Hedden, P. 1987. Gibberellin insensitivity and depletion in wheat: consequences for development. In: Hoad G.V., Lenton J.R., Jackson M.R. and Atkin R.K. (eds). Hormone action in plant development: A critical appraisal. Butterworths, London. pp. $145-160$

Mackinney, G. 1941. Absorption of light by chlorophyll solutions. Journal of Biological Chemistry 140: 315-322.
Mstat,C. 1991. A microcomputer program for design management and analysis of agronomic research experiments. Michigan State University, East Lansing, MI, USA.

Rademacher, W. 1997. Bioregulation of crop plants with inhibitors of gibberellin biosynthesis. Proceedings of Plant Growth Regulation Society of America 24: 27-31.

Ritchie, G.A., Short, K.C. and Davey, M.R. 1991. In vitro acclimatization of chrysanthemum and sugar beet plantlets by treatment with paclobutrazol and exposure to reduced humidity. Journal of Experimental Botany 42: 1557-1563.

Roberts, A.V. and Mathews, D. 1995. The preparation in vitro of chrysanthemum for transplantation to soil. 5. The $2 \mathrm{~s}, 3 \mathrm{~s}$ enantiomers of paclobutrazol improves resistance to desiccation. Plant Cell, Tissue and Organ Culture 40: 191-193.

Salisbury, F.B. and Ross, C.W. 1992. Plant Physiology 4th ed. Wadsworth Publishing Com., California,USA

Sebastian, B., Alberto, G., Emilio, A.C., Jose, A.F. and Juan, A.F. 2002. Growth, development and colour response of potted Dianthus caryophyllus $\mathrm{cv}$. Mondriaan to paclobutrazol treatment. Scientia Horticulturae. 1767: 1-7.

Seyfu, K. 1983. Studies of lodging, floral biology, and breeding techniques in tef (Eragrostis tef (Zucc.) Trotter). Ph.D. thesis, University of London, Royal Hallway College. pp. 122.

Seyfu, K. 1987. Research recommendations for production and brief out-line of strategy for the improvement of tef (Eragrostis tef (Zucc.). Proceedings of the $19^{\text {th }}$ national crop improvement conference 22-25 April, Addis Ababa.

Seyfu, K. 1997. Tef (Eragrostis tef (Zucc.) Trotter). Promoting the conservation and use of underutilized and neglected crops.12. Institute of Plant Genetics and Crop Plant Research, Gatersleben/ International Plant Genetics Resource Institute, Rome, Italy. pp. $1-10$.

Shanahan, J.F. and Nielson, D.C. 1987. Influence of growth retardants on corn vegetative growth, water use and grain yield under different levels of water stress. Agronomy Journal 79(1): 103-109.

Smith, E.F., Gribaudo, I., Roberts, A.V. and Mottely, J. 1992. Paclobutrazol and reduced humidity improves resistance to wilting in micro propagated grapevine. HortScience 27: 111113.

Stitt, M., Von Schaewen, A. and Willmitzer, L. 1990. 'Sink' regulation of photosynthetic 
metabolism in transgenic tobacco plants expressing yeast invertase in their cell wall involves a decrease of the Calvin-cycle enzymes and an increase of glycolytic enzymes. Planta 183: 40-50

Street, J.E., Jordan, J.H., Ebelhar, M.W. and Boykin, D.L. 1986. Plant height and yield response of rice to paclobutrazol. Agronomy Journal 78 (2): 288-291.

Takahashi, N. 1986. Plant growth substances in regulation of life cycle of higher plants. Proceedings International Symposium of Korean Weed Science Society. pp. 1-5.

Tekalign, T. and Hammes, P.S. 2005a. Response of potato grown in a hot tropical lowland to applied paclobutrazol. I: Shoot attributes, assimilate production and allocation. New Zealand Journal of Crop and Horticultural Sciences 33: 35-42.

Tekalign, T., Hammes, P.S. and Robbertse, P.J. 2005b. Paclobutrazol induced leaf, stem, and root anatomy modifications in potato. HortScience 40(4): 1-4.

Vavilove, W.I. 1951. The origin, variation, immunity and breeding of cultivated plants. The Ronalds Press Co., New York. pp. 37-38.

Yim, K.O., Kwon, Y.W. and Bayer, D.E. 1997. Growth responses and allocation of assimilates of rice seedlings by paclobutrazol and gibberellin treatment. Journal of Plant Growth Regulation 16: 35-41.

Young III, W.C., Chilcote, D.O. and Youngberg, H.W. 1996. Seed yield response of perennial ryegrass to low rates of paclobutrazol. Agronomy Journal 88: 951-955.

Young III, W.C., Chilcote, D.O. and Youngberg, H.W. 1999. Chemical dwarfing and the response of cool-season grass seed crops to spring applied nitrogen. Agronomy Journal 91: 344-350.

Zhou, W. and XI., H. 1993. Effects of mixatalol and paclobutrazol on photosynthesis and yield of rape (Brassica napus). Journal of Plant Growth Regulation 12: 157-161. 